Received: 24 September 2018

Revised: 20 October 2018

Accepted: 10 November 2018

Published: 30 December 2018

\title{
Simulasi Prediksi Total Hujan Bulanan di Tanjungpinang (Studi Kasus Tahun 2017)
}

\author{
Diana Cahaya Siregar ${ }^{1, a)}$, Robbi Akbar Anugrah ${ }^{1, b)}$, Tumardi ${ }^{1, c)}$ \\ ${ }^{1}$ Stasiun Meteorologi Tanjungpinang \\ Jl. Adi Sucipto Km. 12.5 Bandara Raja Haji Fisabilillah Tanjungpinang (Kepri) 29125 \\ stamet_bintan@yahoo.co.id,stamet.tanjungpinang@bmkg.go.id
}

Email: ${ }^{\text {a) }}$ siregardianacahaya@gmail.com, b) anugrah.robbi@yahoo.co.id, ${ }^{c}$ tumardi.t@ yahoo.com

\begin{abstract}
The amount of rainfall that occurs in an area is affected by meteorological and non-meteorological factors. Meteorological factors or physical parameters such as air temperature, air pressure, air humidity, wind speed, and solar radiation time are indicated to affect the amount of rainfall. Simulation of the estimated monthly rainfall for 2017 using the 1981-2016 weather parameter data in Tanjungpinang was formulated using the multiple linear regression equation method. Validating of the correct results of the estimated amount of rainfall on the actual rainfall using Pearson Correlation to determine data deviations occurs between predictor to observation data. The data processing results show that the monthly rainfall prediction simulation will be quite good if the weather conditions in an area are in a normal condition which there is no weather and climate anomaly especially on a global, regional and local factor scale.
\end{abstract}

Keywords: monthly rainfall, multiple linear regression, correlation

\begin{abstract}
Abstrak
Jumlah curah hujan yang terjadi di suatu wilayah dipengaruhi faktor meteorologi dan non meteorologi. Faktor meteorologi atau parameter fisik seperti suhu udara, tekanan udara, kelembaban udara, kecepatan angin, dan lama penyinaran matahari diindikasikan dapat mempengaruhi jumlah curah hujan yang terjadi. Simulasi prakiraan jumlah curah hujan bulanan tahun 2017 dengan menggunakan data parameter cuaca periode tahun 1981-2016 di Tanjungpinang telah dilakukan menggunakan metode persamaan regresi linear berganda. Validasi kebenaran hasil prakiraan jumlah curah hujan terhadap curah hujan aktualnya menggunakan Korelasi Pearson untuk mengetahui penyimpangan data yang terjadi antara prediktor dan data observasi. Hasil pengolahan data yang telah dilakukan menunjukkan bahwa simulasi prediksi curah hujan bulanan akan cukup baik apabila kondisi cuaca di suatu wilayah dalam keadaan normal dimana tidak terdapat anomali cuaca dan iklim baik dalam skala global, regional maupun lokal.
\end{abstract}

Kata-kata kunci: hujan bulanan, regresi linear berganda, korelasi

\section{PENDAHULUAN}

Wilayah Indonesia berada di daerah tropis yang selalu mendapatkan surplus energi matahari sehingga menjadi daerah konvektif paling aktif dibandingkan wilayah ekuatorial lainnya (Tjasyono, 2007). Kesulitan dalam memprediksi cuaca di Indonesia dikarenakan fenomena cuaca yang dapat berubah dengan cepat. Akibatnya pola sebaran curah hujan cenderung tidak merata untuk tiap daerah 
yang ada di Indonesia dalam ruang lingkup yang luas (Swarinoto dan Sugiyono, 2011, h.272). Hujan sering sekali dianggap sebagai presipitasi. Hujan berasal dari uap air yang ada di atmosfer, sehingga bentuk dan jumlahnya dipengaruhi oleh faktor klimatologi seperti angin, suhu udara, dan tekanan atmosfer.

Pembangunan dan mobilitas masyarakat di Tanjungpinang yang cukup pesat berdampak terhadap perubahan pola cuaca yang signifikan khususnya terjadi kenaikan suhu udara dan frekuensi kejadian hujan lebat yang semakin sering terjadi, Pola kekhasan cuaca di Tanjungpinang dipengaruhi oleh letak geografisnya yang di kelilingi langsung oleh perairan sehingga konvektifitas yang terjadi lebih banyak dipengaruhi oleh faktor lokal. Tanjungpinang memiliki tipe hujan ekuatorial dimana puncak musim hujan terjadi pada bulan Mei dan November. Pada bulan-bulan tersebut Tanjungpinang memiliki curah hujan yang cukup tinggi, sehingga sangat perlu diwaspadai potensi terjadinya cuaca buruk. Pemanasan global yang semakin marak, perubahan iklim yang semakin sering terjadi, dan dampak urban heat dari kota-kota di Tanjungpinang dianggap sebagai faktor yang dapat memicu terjadinya hujan lebat di Tanjungpinang.

Kajian ini berupaya membuat simulasi faktor parameter cuaca dalam mempengaruhi jumlah curah hujan bulanan di Tanjungpinang. Pengolahan data suhu udara, tekanan udara, kelembaban udara, kecepatan angin, dan lama penyinaran matahari selama periode 1981-2016 digunakan untuk pembuatan simulasi prediksi total hujan bulanan untuk periode tahun 2017. Metode yang digunakan untuk simulasi prediksi total hujan bulanan yaitu metode regresi linier berganda. Hasil perhitungan dalam analisis ini akan diolah menggunakan Microsoft Excel. Prediksi total hujan bulanan akan berbeda-beda untuk tiap daerah sehingga sangat perlu dilakukannya evaluasi terhadap prediksi total hujan bulanan yang sudah ada (Fadholi, 2013, h.7).

\section{METODE}

Data yang digunakan dalam penelitian ini menggunakan data parameter cuaca dari Stasiun Meteorologi Tanjungpinang periode tahun 1981-2017. Adapun data parameter cuaca yang digunakan, yaitu: jumlah curah hujan bulanan, suhu udara rata-rata bulanan, kelembaban udara rata-rata bulanan, tekanan udara rata-rata bulanan, kecepatan angin rata-rata bulanan, dan jumlah lama penyinaran matahari rata-rata bulanan. Data parameter cuaca periode 1981-2016 digunakan untuk membuat simulasi prediksi total hujan bulanan periode tahun 2017. Data jumlah curah hujan hasil observasi pada tahun 2017 akan digunakan sebagai verifikator untuk mengevaluasi hasil model output simulasi prediksi yang diperoleh dari pengolahan data periode tahun 1981-2017.

Metode regresi menggunakan dua jenis variabel yaitu variabel bebas (independen) dan variabel tidak bebas (dependen). Variabel bebas yang dinyatakan dengan $x$ berperan sebagai variabel yang dapat mempengaruhi (memprediksi nilai) variabel tidak bebas. Variabel tidak bebas yang dinyatakan dengan $y$ merupakan variabel yang terjadi (hasil) karena variabel bebas. Dalam kajian ini, metode yang digunakan yaitu metode regresi linear berganda. Menurut Jaya (2010, h. 172) metode regresi linear berganda digunakan untuk meramalkan bagaimana keadaan (naik turunnya) variabel dependen bila dua atau lebih variabel independen sebagai prediktor dimanipulasi (dinaik turunkan nilainya). Metode regresi linear berganda digunakan untuk melakukan simulasi prediksi jumlah curah hujan bulanan yang menggunakan variabel independen lebih dari satu. Adapun variabel independen, yaitu: suhu udara, kelembaban udara, tekanan udara, kecepatan angin, dan lama penyinaran matahari. Variabel dependen yaitu curah hujan.

Persamaan umum metode regresi linear berganda, yaitu:

Keterangan :

$$
Y=B_{0}+B_{1} X_{1}+B_{2} X_{2}+\cdots+B_{n} X_{n}
$$

$B_{0}=$ konstanta

$B=$ koefisien variabel dari $X$

$Y=$ variabel yang diduga (variabel dependen)

$X=$ variabel penduga (variabel independen) 
Proses pembuatan simulasi prediksi ada dua tahapan. Tahap pertama yaitu membuat persamaan regresi setiap bulan selama 36 tahun dari tahun 1981-2016. Tahap kedua yaitu memprediksi total hujan bulanan dengan memberikan nilai variabel penduga (prediktor) pada persamaan regresi yang telah dibuat pada tahap pertama. Selanjutnya akan dilakukan evaluasi terhadap persamaan regresi menggunakan Korelasi Pearson (r). Korelasi Pearson (r) digunakan untuk mengetahui nilai penyimpangan antara nilai prediksi total hujan $(x)$ dengan nilai total hujan aktualnya yang berasal dari data hasil observasi $(y)$ untuk tahun 2017. Dari nilai $\mathrm{r}$, dapat dilakukan analisa nilai prediksi jumlah curah hujan tersebut memiliki nilai penyimpangan besar atau kecil.

Keterangan:

$$
r(x, y)=\frac{n \cdot \sum X Y-\sum X \cdot \sum Y}{\sqrt{\left\{n \cdot \sum X^{2}-\left(\sum X\right)^{2}\right\} \cdot\left\{\left(n \cdot \sum Y^{2}-\left(\sum Y\right)^{2}\right\}\right.}}
$$

$r=$ nilai yang menyatakan korelasi antara variabel $x$ dan variabel $y$

Menurut Sugiyono (2011, h.184) nterpretasi korelasi (r) dibagi menjadi 5 kriteria pada Tabel 1.

TABEL 1. Kriteria koefisien korelasi

\begin{tabular}{|c|c|c|}
\hline No & Kriteria & Interpretasi Data \\
\hline 1 & Sangat Rendah & $0,0-0,199$ \\
\hline 2 & Rendah & $0,2-0,399$ \\
\hline 3 & Sedang & $0,4-0,599$ \\
\hline 4 & Kuat & $0,6-0,799$ \\
\hline 5 & Sangat Kuat & $0,8-1,0$ \\
\hline
\end{tabular}

\section{HASIL DAN PEMBAHASAN}

Analisis pengaruh dari suhu udara $\left(\mathrm{X}_{1}\right)$, tekanan udara $\left(\mathrm{X}_{2}\right)$, kelembaban udara $\left(\mathrm{X}_{3}\right)$, kecepatan angin $\left(\mathrm{X}_{4}\right)$, dan lama penyinaran matahari $\left(\mathrm{X}_{5}\right)$ terhadap curah hujan disimulasikan dalam bentuk persamaan dari metode regresi liear berganda yang ditampilkan pada Tabel 2. Data series panjang (periode tahun 1981-2016) digunakan untuk melihat pola trend untuk menghitung persamaan prediktor. Persamaan tersebut digunakan untuk menghitung nilai curah hujan periode 2017 yang terjadi di wilayah Tanjungpinang. Selanjutnya akan divaliadasi hasil prediksi curah hujan terhadap data curah hujan in situ (observasi) periode 2017.

TABEL 2. Metode regresi linear berganda dengan prediktor parameter cuaca

\begin{tabular}{ccc}
\hline No & Bulan & Metode Regresi Linear Berganda \\
\hline 1 & Januari & $\mathrm{Y}=-32316.89-25.48 \mathrm{X}_{1}+30.67 \mathrm{X}_{2}+32.25 \mathrm{X}_{3}-47.75 \mathrm{X}_{4}-5.79 \mathrm{X}_{5}$ \\
2 & Februari & $\mathrm{Y}=6.43+3.62 \mathrm{X}_{1}+0.132 \mathrm{X}_{2}-0.0008 \mathrm{X}_{3}+0.00334 \mathrm{X}_{4}-0.08 \mathrm{X}_{5}$ \\
3 & Maret & $\mathrm{Y}=45.02-2.02 \mathrm{X}_{1}-0.0023 \mathrm{X}_{2}-0.02 \mathrm{X}_{3}+1.27 \mathrm{X}_{4}+1.26 \mathrm{X}_{5}$ \\
4 & April & $\mathrm{Y}=89.02-0.07 \mathrm{X}_{1}+0.05 \mathrm{X}_{2}+0.01 \mathrm{X}_{3}+0.04 \mathrm{X}_{4}+0.0043 \mathrm{X}_{5}$ \\
5 & Mei & $\mathrm{Y}=215.38+0.26 \mathrm{X}_{1}+0.26 \mathrm{X}_{2}+0.10 \mathrm{X}_{3}+0.01 \mathrm{X}_{4}+0.02 \mathrm{X}_{5}$ \\
6 & Juni & $\mathrm{Y}=341.36-0.31 \mathrm{X}_{1}-0.05 \mathrm{X}_{2}+0.15 \mathrm{X}_{3}+0.0035 \mathrm{X}_{4}+0.0049 \mathrm{X}_{5}$ \\
7 & Juli & $\mathrm{Y}=273.58-0.23 \mathrm{X}_{1}-0.14 \mathrm{X}_{2}+0.08 \mathrm{X}_{3}+0.02 \mathrm{X}_{4}+0.06 \mathrm{X}_{5}$ \\
8 & Agustus & $\mathrm{Y}=93.09-3.05 \mathrm{X}_{1}+0.16 \mathrm{X}_{2}-0.10 \mathrm{X}_{3}+0.02 \mathrm{X}_{4}+0.04 \mathrm{X}_{5}$ \\
9 & September & $\mathrm{Y}=458.79-0.42 \mathrm{X}_{1}-0.12 \mathrm{X}_{2}+0.14 \mathrm{X}_{3}+0.01 \mathrm{X}_{4}-0.07 \mathrm{X}_{5}$
\end{tabular}




\begin{tabular}{lcr}
10 & Oktober & $\mathrm{Y}=357.93+1.31 \mathrm{X}_{1}-0.20 \mathrm{X}_{2}+0.02 \mathrm{X}_{3}+0.0015 \mathrm{X}_{4}+0.01 \mathrm{X}_{5}$ \\
11 & November & $\mathrm{Y}=258.46-0.24 \mathrm{X}_{1}+0.07 \mathrm{X}_{2}-0.02 \mathrm{X}_{3}+0.02 \mathrm{X}_{4}+0.02 \mathrm{X}_{5}$ \\
12 & Desember & $\mathrm{Y}=304.37-0.28 \mathrm{X}_{1}+0.03 \mathrm{X}_{2}+0.10 \mathrm{X}_{3}+0.02 \mathrm{X}_{4}+0.03 \mathrm{X}_{5}$ \\
\hline
\end{tabular}

Persamaan yang ada pada Tabel 2 digunakan untuk menghitung prediksi nilai curah hujan periode 2017 dengan memasukkan nilai parameter cuaca periode tahun 2017 dimana parameter cuaca yang dimaksudkan, yaitu: suhu udra, tekanan udara, kelemababan udara, kecepatan angin, dan lama penyinaran matahari pada tahun 2017. Selanjutnya akan diperoleh nilai hasil prediksi curah hujan tahun 2017. Hubungan antara jumlah curah hujan hasil prediksi menggunakan persamaan regresi lineai berganda dengan jumlah curah hujan aktualnya akan dihitung menggunakan Korelasi Pearson (r). Nilai $\mathrm{r}$ dari keduanya disajikan pada Tabel 3. Perlu diketahui bahwa jika total hujan hasil observasi mengalami kenaikan dan total hujan hasil prediksi juga mengalami kenaikan atau sebaliknya, maka dapat dikatakan bahwa prediksi tersebut mendekati total hujan yang sebenarnya dan hasil prediksi tersebut adalah cukup baik. Jumlah curah hujan baik prediksi dan observasi mengalami kenaikan sebanding terjadi pada bulan April-Mei, Agustus-September, dan Oktober-November.

Validasi dengan perhitungan $r$ didominasi pada kriteria sedang berkisar $0.4-0.6$ (Tabel 3). Nilai $r$ pada kriteria sedang terjadi pada bulan Januari, Mei, Juli, Agustus, September, Oktober, dan November. Nilai r pada kriteria rendah terjadi pada bulan Februari, Maret, dan Desember. Nilai r pada kriteria sangat rendah terjadi pada bulan April. Nilai $r$ yang bernilai negatif menandakan hubungan terbalik antara prediktor dengan data observas seperti yang terjadi pada bulan Juni. Hal ini mununjukkan niai $r$ masih dipengaruhi oleh faktor-faktor pendukung lainnya. Nilai $r$ juga dapat dipengaruhi oleh fenomena atmosfer dan faktor lokal meteorologi. Curah hujan yang terjadi di wilayah Tanjungpinang dapat dipengaruhi oleh berbagai faktor cuaca selain suhu udara, tekanan udara, kelembaban udara, kecepatan angin yang bertiup, dan lama peyinaran matahari yang tercatat selama sehari.

TABEL 3. Nilai r, curah hujan prediksi dan observasi untuk tahun 2017

\begin{tabular}{|c|c|c|c|c|}
\hline \multirow{2}{*}{ No } & \multirow{2}{*}{ Bulan } & $\mathrm{r}$ & \multicolumn{2}{|c|}{ Curah hujan (2017) } \\
\cline { 4 - 5 } & & & Prediksi & Observasi \\
\hline 1 & Januari & 0.51 & 298.1 & 271.4 \\
2 & Februari & 0.27 & 230.7 & 238.8 \\
3 & Maret & 0.26 & 189.7 & 271.5 \\
4 & April & 0.09 & 139.0 & 353 \\
5 & Mei & 0.47 & 495.1 & 527.5 \\
6 & Juni & -0.03 & 297.7 & 167.5 \\
7 & Juli & 0.45 & 136.3 & 133.9 \\
8 & Agustus & 0.50 & 165.5 & 114 \\
9 & September & 0.51 & 334.2 & 290.4 \\
10 & Oktober & 0.47 & 193.2 & 234.1 \\
11 & November & 0.50 & 321.7 & 311.4 \\
12 & Desember & 0.22 & 337.1 & 251 \\
\hline
\end{tabular}

Nilai prediksi total hujan bulanan pada bulan Januari 2017 yaitu 298,1 mm. Nilai observasi total hujan bulanan yang terakumulasi pada bulan ini sebesar $271,4 \mathrm{~mm}$. Penyimpangan terhadap data total hujan aktualnya yaitu sebesar $26,7 \mathrm{~mm}$.

Nilai prediksi total hujan bulanan pada bulan Februari 2017 yaitu 230,7 mm. Nilai observasi total hujan bulanan yang terakumulasi pada bulan ini sebesar $238,8 \mathrm{~mm}$. Penyimpangan terhadap data total hujan aktualnya yaitu sebesar $8,1 \mathrm{~mm}$. 
Nilai prediksi total hujan bulanan pada bulan Maret 2017 yaitu 189,7 mm. Nilai observasi total hujan bulanan yang terakumulasi pada bulan ini sebesar $271,5 \mathrm{~mm}$. Penyimpangan terhadap data total hujan aktualnya yaitu sebesar $81,8 \mathrm{~mm}$.

Nilai prediksi total hujan bulanan pada bulan April 2017 yaitu 139,0 mm. Nilai observasi total hujan bulanan yang terakumulasi pada bulan ini sebesar $353,0 \mathrm{~mm}$. Penyimpangan terhadap data total hujan aktualnya yaitu sebesar 214,0 mm.

Nilai prediksi total hujan bulanan pada bulan Mei 2017 yaitu 495,1 mm. Nilai observasi total hujan bulanan yang terakumulasi pada bulan ini sebesar $527,5 \mathrm{~mm}$. Penyimpangan terhadap data total hujan aktualnya yaitu sebesar $32,4 \mathrm{~mm}$.

Nilai prediksi total hujan bulanan pada bulan Juni 2017 yaitu 297,7 mm. Nilai observasi total hujan bulanan yang terakumulasi pada bulan ini sebesar $167,5 \mathrm{~mm}$. Penyimpangan terhadap data total hujan aktualnya yaitu sebesar 130,2 $\mathrm{mm}$.

Nilai prediksi total hujan bulanan pada bulan Juli 2017 yaitu 136,3 mm. Nilai observasi total hujan bulanan yang terakumulasi pada bulan ini sebesar $133,9 \mathrm{~mm}$. Penyimpangan terhadap data total hujan aktualnya yaitu sebesar $2,4 \mathrm{~mm}$.

Nilai prediksi total hujan bulanan pada bulan Agustus 2017 yaitu 165,5 mm. Nilai observasi total hujan bulanan yang terakumulasi pada bulan ini sebesar $114,0 \mathrm{~mm}$. Penyimpangan terhadap data total hujan aktualnya yaitu sebesar $51,5 \mathrm{~mm}$.

Nilai prediksi total hujan bulanan pada bulan September 2017 yaitu 334,2 mm. Nilai observasi total hujan bulanan yang terakumulasi pada bulan ini sebesar 290,4 $\mathrm{mm}$. Penyimpangan terhadap data total hujan aktualnya yaitu sebesar $43,8 \mathrm{~mm}$.

Nilai prediksi total hujan bulanan pada bulan Oktober 2017 yaitu 193,2 mm. Nilai observasi total hujan bulanan yang terakumulasi pada bulan ini sebesar $234,1 \mathrm{~mm}$. Penyimpangan terhadap data total hujan aktualnya yaitu sebesar $40,9 \mathrm{~mm}$.

Nilai prediksi total hujan bulanan pada bulan November 2017 yaitu $321,7 \mathrm{~mm}$. Nilai observasi total hujan bulanan yang terakumulasi pada bulan ini sebesar $311,4 \mathrm{~mm}$. Penyimpangan terhadap data total hujan aktualnya yaitu sebesar $10,3 \mathrm{~mm}$.

Nilai prediksi total hujan bulanan pada bulan Desember 2017 yaitu 337,1 mm. Nilai observasi total hujan bulanan yang terakumulasi pada bulan ini sebesar 251,0 $\mathrm{mm}$. Penyimpangan terhadap data total hujan aktualnya yaitu sebesar $86,1 \mathrm{~mm}$.

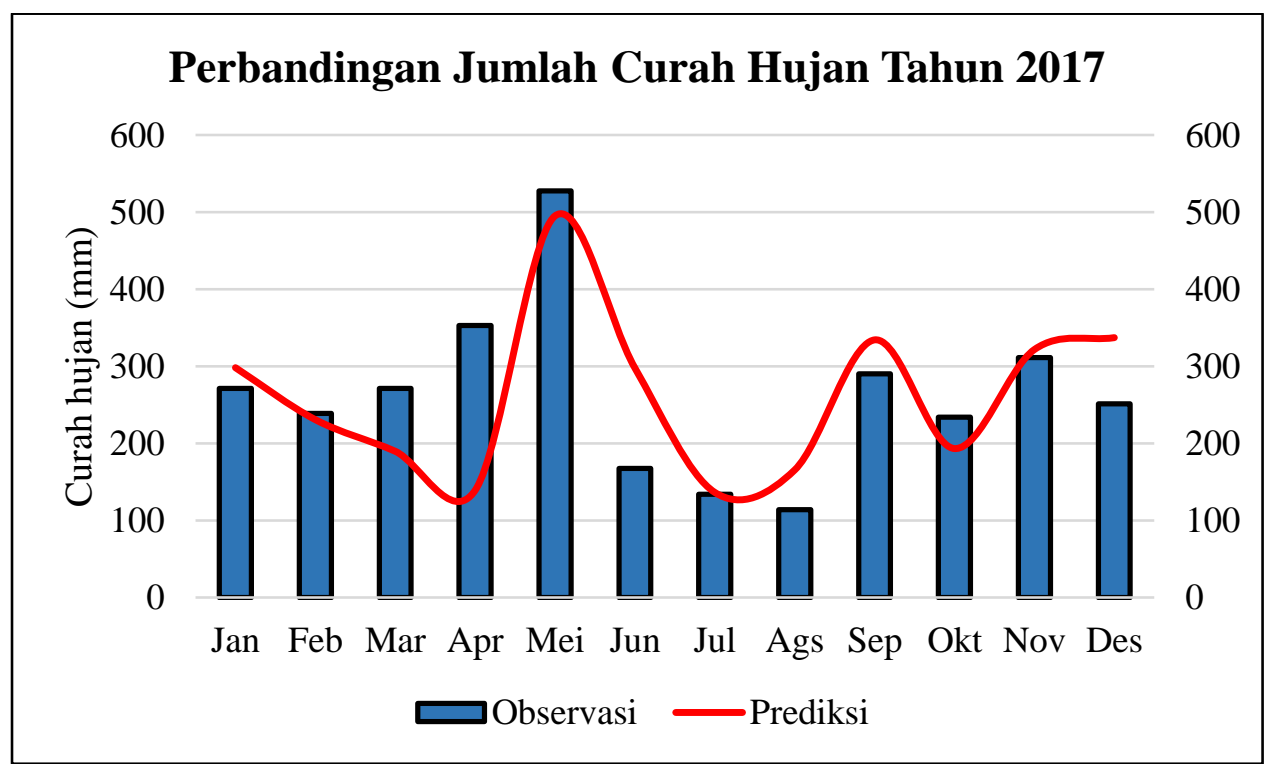

GAMBAR 1. Perbandingan jumlah curah hujan prediksi dan curah hujan observasi

Gambar 1 menampilkan nilai perbandingan jumlah curah hujan prediksi dan curah hujan observasi untuk tahun 2017. Grafik prediksi total hujan bulanan terhadap grafik total hujan hasil observasi 
memiliki pola cenderung teratur dan terlihat prediksi total hujan cenderung mengikuti total hujan aktualnya. Ketika total hujan hasil observasi mengalami kenaikan maka prediksi total hujan juga mengalami kenaikan. Kondisi sebaliknya terjadi ketika total hujan observasi mengalami penurunan maka prediksi total hujan juga mengalami penurunan. Analisa Gambar 1 menunjukkan hasil prediksi jumlah hujan bulanan secara umum kenaikan dan penurunannya selaras dengan data jumlah curah hujan aktualnya, namun pada bulan-bulan tertentu seperti bulan: Maret, April, Juni, Agustus, dan Desember, terjadi penyimpangan jumlah curah hujan yang cukup besar.

Analisis temporal curah hujan pada Gambar 1 menunjukkan grafik curah hujan rata-rata bulanan di Tanjungpinang memiliki dua puncak curah hujan tertinggi yang terjadi selama setahun. Curah hujan tertinggi terjadi pada Bulan Mei dan November dengan curah hujan berkisar 300-500 mm, sedangkan curah hujan terendah berkisar antara Bulan Juli dan Agustus dengan kisaran curah hujan antara 100 $150 \mathrm{~mm}$. Pola hujan di wilayah Tanjungpinang dikategorikan pola ekuatorial dikarenakan terdapat dua puncak curah hujan dalam setahun.

Anomali jumlah curah hujan bulanan dimungkinkan terjadi akibat faktor cuaca dan iklim seperti faktor global, regional dan lokal yang berpengaruh langsung terhadap pola keseimbangan cuaca di wilayah Tanjungpinang. Selain parameter cuaca yang digunakan dalam penelitian ini, satu faktor pengendali cuaca bumi yaitu gerak semu matahari juga berpengaruh terhadap proses konveksi yang terjadi di wilayah Tanjungpinang. Proses konveksi berlangsung karena adanya pemanasan terusmenerus sehingga akan terbentuk awan-awan konvektif. Giatnya konvektifitas antara atmosfer dan lautan yang mengelilingi Pulau Bintan dapat menyebabkan hujan yang bersifat lokal dapat terjadi di wilayah Pulau Bintan khususnya di wilayah Tanjungpinang.

\section{KESIMPULAN DAN SARAN}

\section{Kesimpulan}

Prediksi total hujan bulanan menggunakan parameter cuaca yang banyak dengan menggunakan metode regresi linier berganda akan menghasilkan luaran (output) yang relatif lebih baik jika dibandingkan dengan satu parameter cuaca saja sebagai prediktor. Prediksi jumlah curah hujan bulanan akan cukup baik terinterpretasikan apabila kondisi cuaca di suatu wilayah dalam keadaan normal (tidak terdapat anomali cuaca dan iklim baik dalam skala global, regional dan faktor lokal).

\section{Saran}

Nilai prediksi jumlah curah hujan dengan prediktor parameter cuaca di Tanjungpinang yang sudah dikaji dalam penelitian ini,dapat dikaji dan dijadikan sebagai referensi untuk prakiraan jumlah curah hujan di lokasi lain. Penulisan ini bisa dikembangkan lebih lanjut dengan menambahkan prediktor unsurunsur cuaca yang lebih banyak lagi.

\section{UCAPAN TERIMA KASIH}

Terima kasih kepada Kepala beserta Staf yang bekerja di Stasiun Meteorologi Tanjungpinang yang telah membantu dalam penyediaan data sehingga penelitian ini dapat diselesaikan.

\section{REFERENSI}

Fadholi, A 2013, 'Persamaan Regresi Prediksi Curah Hujan Bulanan Menggunakan Data Suhu dan Kelembapan Udara di Ternate', Jurnal Statistika, vol. 13, no. 17, hh 7-16.

Fadholi, A 2013, 'Pemanfaatan Suhu Udara dan Kelembaban Udara dalam Persamaan Regresi untuk Simulasi Prediksi Total Hujan Bulanan di Pangkalpinang', Jurnal CAUCHY, ISSN: 20860382, vol.3, no. 1, hh 1-9. 
Jaya, I 2010, Statistik Penelitian untuk Pendidikan, Penerbit Citapustaka Media Perintis, Bandung.

Sugiyono 2011, Metode Penelitian Kuantitatif, Kualitatif, dan R\&D, Penerbit Alfabeta, Bandung.

Swarinoto, YS \& Sugiyono 2013, 'Pemanfaatan Suhu Udara dan Kelembapan Udara Dalam Persamaan Regresi Untuk Simulasi Prediksi Total Hujan Bulanan di Bandar Lampung', Jurnal Meteorologi dan Geofisika, vol. 12, no. 3, hh. 271-281.

Tjasyono, HKB 2007, Meteorologi Indonesia 1 Karakteristik dan Sirkulasi Atmosfer, Badan Meteorologi dan Geofisika, Jakarta. 